\title{
Effect of Solid Solution and Ageing Treatments on the Microstructure and Mechanical Properties of the SiCp/Al-Si-Cu-Mg Composite
}

DOI: $10.15255 / \mathrm{KUI} .2016 .025$ KUI-27/2017 Original scientific paper Received June 15, 2016 Accepted September 21, 2016

\author{
A. -Q. Wang, ${ }^{a^{*}, b}$ H.-D. Guo, ${ }^{a}$ H.-H. Han, ${ }^{a}$ and J.-P. Xie ${ }^{a, b}$ \\ a School of Materials Science and Engineering, Henan University of Science and Technology, \\ Luoyang, P.R. China \\ ${ }^{b}$ Collaborative Innovation Center of Non-Ferrous Materials of Henan Province, P.R. China
}

\begin{abstract}
$\|$ Abstract
The $\mathrm{SiC}$ particles (SiCp, mass fraction $30 \%$ ) reinforced with the $\mathrm{Al}-\mathrm{Si}-\mathrm{Cu}-\mathrm{Mg}$ matrix composite have been prepared using one-way press method, sintering, and hot extrusion. The composite was subjected to solid solution treatment at temperatures of $470{ }^{\circ} \mathrm{C}, 485^{\circ} \mathrm{C}, 500{ }^{\circ} \mathrm{C}, 515^{\circ} \mathrm{C}$, and $530^{\circ} \mathrm{C}$ for $4 \mathrm{~h}$. The sample was then subjected to ageing treatment at temperatures of $160{ }^{\circ} \mathrm{C}$ and $180^{\circ} \mathrm{C}$ during different times after solid solution treatment at $515{ }^{\circ} \mathrm{C}$ for $4 \mathrm{~h}$. The microstructure and mechanical properties of the SiCp/Al-Si-Cu-Mg matrix composite under the different ageing and solid solution treatments were tested using SEM and TEM microhardness analysis. The results show that the white granulated metallic compounds of the SiCp/Al-Si-Cu-Mg composite materials, which are formed in the sintering process of composite materials, dissolve back after the solid solution treatment at different temperatures. The higher the solid solution temperature, the more metallic compounds dissolve back. The microhardness of the composites reached maximum after solution treatment at $515{ }^{\circ} \mathrm{C}$ for $4 \mathrm{~h}$. Following the ageing treatment and with the prolongation of ageing time, the hardness of the composite material reached "double peak" phenomenon. With the increase in ageing temperature, the hardening speed of the composite material also increased, but at the same time, the hardening ability had reduced. After the ageing treatment, the second phases of the composite are discoid $\mathrm{Al}_{5} \mathrm{Cu}_{6} \mathrm{Mg}_{2}$.

\section{$\|$ Keywords}

SiCp/Al-Si-Cu-Mg composite, solid solution treatment, ageing treatment, microstructure, microhardness
\end{abstract}

\section{Introduction}

The SiC particle reinforced with the Al-Si-Cu-Mg composite material possesses high specific strength, high specific stiffness, low thermal expansion coefficient, good abrasion resistance, and excellent performance, making it hot research material. It has been widely used in the aerospace and electronic fields for nearly 30 years. ${ }^{1-3}$ The matrix alloy of the SiCp/Al-Si-Cu-Mg composites (SiC particle reinforced with $\mathrm{Al}-\mathrm{Si}-\mathrm{Cu}-\mathrm{Mg}$ ) was prepared by powder metallurgy typically by the atomization method. In the process of sintering, the matrix of the alloy is in the supersaturated state. The supersaturated alloying elements precipitate from the substrate to form larger metal compounds, which can seriously influence the mechanical properties of the composite materials. The heat treatment of the Al-Si-Cu$\mathrm{Mg}$ alloy is the main strengthening mechanism, which can effectively improve the mechanical properties of the composite materials. The solid solution and ageing treatment directly affect the size of the precipitated phase, quantity and distribution, thus influencing the performance of the material. These metal compounds dissolve back by solid solution treatment, and then form nanodispersed phase in the ageing treatment. These nanoparticles can effectively prevent the dislocation movement, and therefore significantly improve the performance of the composite materials. Every solid solution ageing process for improv-

* Corresponding author: Prof Ai-qin Wang

e-mail: aiqin_wang888@163.com ing the performance of a composite material is different. Therefore, the study of the solid solution and ageing process of the SiCp/Al-Si-Cu-Mg matrix composites to further improve the performance of the material is of great significance. $^{4-5}$ In this paper, the research of SiCp/Al-Si-Cu-Mg composite material, with mass fraction of $\mathrm{SiC} 30 \%$, has been conducted by one-way cold pressing, sintering, and hot extrusion, after undergoing solid solution and ageing treatments. This experiment mainly studied the effect of different heat treatment temperatures and times on the microstructure and mechanical properties of the composite materials in order to determine the optimal ageing temperature of the material, and to provide the theory basis for the heat treatment system of the SiCp/Al-Si-Cu-Mg matrix composites.

\section{Experimental materials and method}

The mass fraction of the $\mathrm{SiC}$ particles as a reinforcement material in the composites was $30 \%$. The average size of the $\mathrm{SiC}$ particles was $5 \mu \mathrm{m}$. The Al-Si-Cu-Mg alloy powder (used as a matrix, prepared by the atomization method) was oversaturated. The chemical composition of the aluminium matrix alloy was $19.3 \% \mathrm{Si}, 1.5 \% \mathrm{Cu}, 0.8 \% \mathrm{Mg}$, and the remainder was Al. The average particle size of the Al-Si-Cu-Mg alloy was $10 \mu \mathrm{m}$ and the particles were spherical or ellipsoidal. 
The two materials were mixed in a high-energy ball mill for $10 \mathrm{~h}$ at a revolving speed of $50 \mathrm{rpm}$. The balls and powder were blended with the ratio of $2: 1$. The material composite was made by unidirectional cold pressing after mixing. The stress of $500 \mathrm{MPa}$ was applied to the powders for $0.5 \mathrm{~h}$, followed by sintering at $560^{\circ} \mathrm{C}$ for $4 \mathrm{~h}$. The preparation of the $\mathrm{SiC}$ particle (mass fraction $30 \%$ ) reinforced aluminium matrix composites extruded bars of 20-mm diameter through hot extrusion at $480{ }^{\circ} \mathrm{C}$. The bars were cut into specimens by wire cutting $(10 \mathrm{~mm} \times 10 \mathrm{~mm} \times 15 \mathrm{~mm})$.

The specimens were subjected to solid solution treatment at temperatures of $470{ }^{\circ} \mathrm{C}, 485{ }^{\circ} \mathrm{C}, 500{ }^{\circ} \mathrm{C}, 515^{\circ} \mathrm{C}$, and $530^{\circ} \mathrm{C}$ for $4 \mathrm{~h}$ respectively, followed by quenching in cold water quickly. After the solution conditions at $515{ }^{\circ} \mathrm{C}$ for $4 \mathrm{~h}$, the specimens were aged for different times at $160{ }^{\circ} \mathrm{C}$ and $180{ }^{\circ} \mathrm{C}$, respectively. The samples were cleaned by polishing, rough grinding, and fine grinding until the surfaces were scratchless. The metallographic samples were etched using Keller's reagent. The microstructure of the specimens was observed by JSW-5610 scanning electron microscope under different solid solution temperatures. The hardness of the composite materials was measured in MH-3 type Vickers hardness tester (load of $300 \mathrm{~g}$, holding time of 10 s). Every specimen was measured at 10 points, and their average value calculated. The specimens for TEM observation were machined into $0.3 \mathrm{~mm}$ using wire electrode cutting, which were thinned to $50 \mu \mathrm{m}$ or less by hand and then cut into foils $3 \mathrm{~mm}$ in diameter. The foils were then prepared by an ion beam thinner using the GATAN-691 precision ion polishing system. The transmission electron microscopy (TEM) of the SiCp/Al-Si-Cu-Mg material composite was investigated on JEM-2100 TEM microscope.

\section{Results and discussion}

\subsection{Effect of solid solution on the microstructure of SiCp/Al-Si-Cu-Mg composite}

The SEM images of the SiCp/Al-Si-Cu-Mg composite after hot extrusion without heat treatment at four different temperatures and after solid solution treatment are shown in Fig. 1. The figure shows that the $\mathrm{SiC}$ particles are darker, while the Si particles are shallow and round. In addition, there was a considerable volume fraction of micron white particles in the composite. The SiC particles had a little agglomeration in the composite. The silicon particles and silicon carbide particles were distributed alternatively in
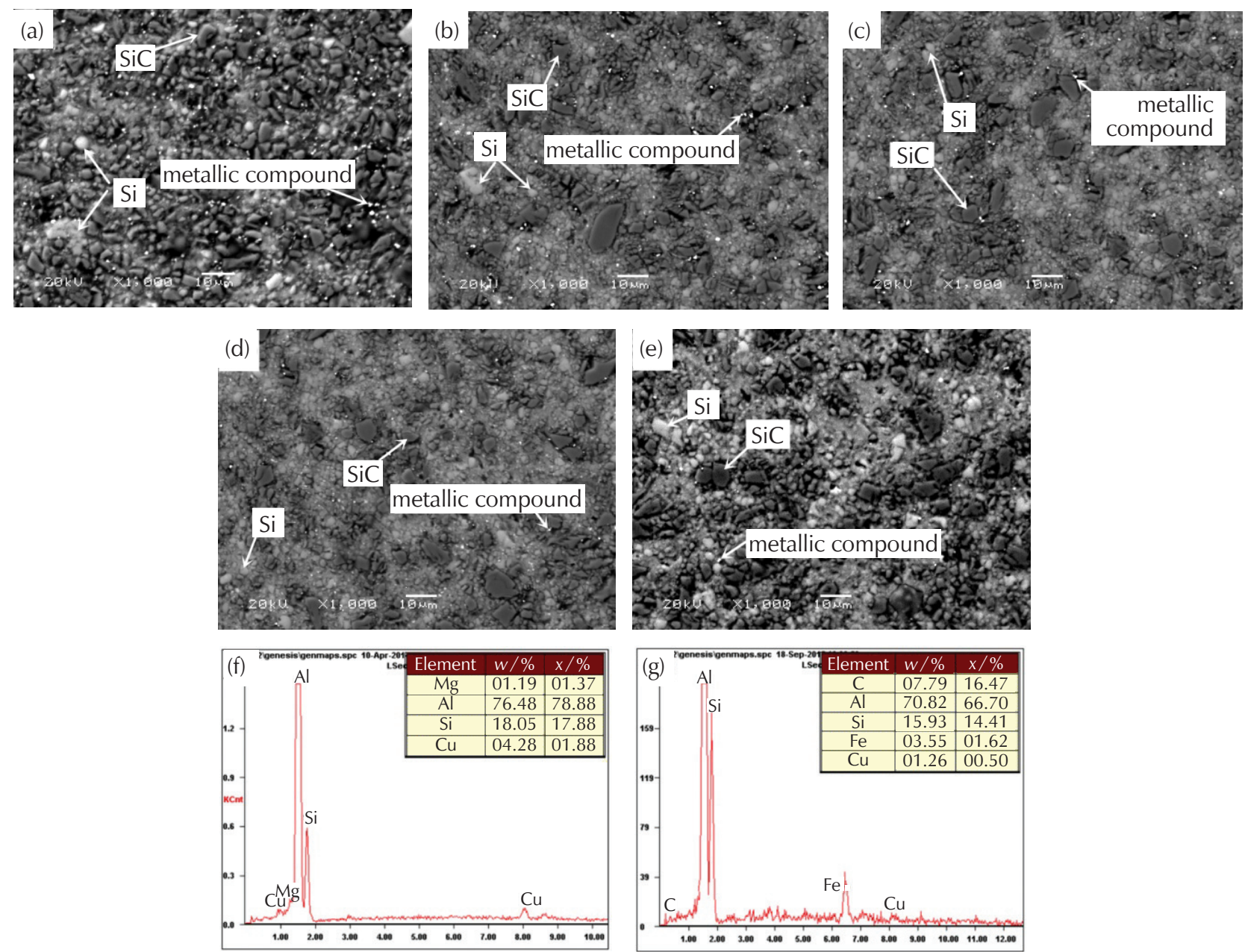

Fig. 1 - SEM images of different solution temperatures: a) Untreated state; b) $470{ }^{\circ} \mathrm{C}$; c) $485{ }^{\circ} \mathrm{C}$; d) $500{ }^{\circ} \mathrm{C}$; e) $515{ }^{\circ} \mathrm{C}$; f) $\mathrm{EDS}$ spectra of metallic compound shown in Fig. 2a; g) EDS spectra of metallic compound shown in Fig. $2 \mathrm{e}$ 
the composite structure. As the silicon carbide and powder grain size was small, there were many nanosized particles in the mixed microparticles. The particles surface had high surface energy. Therefore, the distribution uniformity of SiC particles was improved with a high-energy ball mill, but there is still a little reunion. On the other hand, the plastic deformation of the SiCp/Al-Si-Cu-Mg composite occured in the process of the hot extrusion, and the SiC particles had almost no plastic deformation ability, therefore in the extrusion process, the particles were redistributed and gathered together. ${ }^{6}$

As may be seen from Fig. 1, the metallic compounds are dispersed in the matrix with white round particles. The average size of the metallic compounds was less than $1 \mu \mathrm{m}$. As shown in Fig. 1a, the composites were not heat-treated. Many white round granular metallic compounds are distributed in the matrix. This is due to the matrix being prepared by the atomizing method and the alloying elements in the matrix being supersaturated. These alloying elements precipitate in the sintering and hot extrusion process. Fig. $1 \mathrm{~b}$ shows the morphology of the composite when it was subjected to solution treatment at $470{ }^{\circ} \mathrm{C}$. Compared to the untreated sample, the number of metal compounds had decreased, but there were still many metallic compounds in the matrix, due to the low solution temperature, and the metallic compounds could not fully dissolve back into the matrix alloy. With the increase in the solution temperature, the metallic compounds became more and more fully dissolved into the matrix, and the metallic compounds precipitates had reduced. As shown in Fig. 1d, when the composite was subjected to the solution treatment at $515{ }^{\circ} \mathrm{C}$ for $4 \mathrm{~h}$, the metallic compounds had almost dissolved back into the matrix, with only very little amounts of the metallic compounds remaining insoluble in the matrix. The precipitated metal compound in Fig. 3a underwent SEM energy spectrum analysis (Fig. 3f). The EDS analysis shown in Fig. If suggests that the metallic compounds are rich in $\mathrm{Al}, \mathrm{Cu}$, and $\mathrm{Mg}$ elements. The precipitated metal compound in Fig. 3e was subjected to an SEM energy spectrum analysis (Fig. 3g). The EDS analysis in Fig. 1g suggests that the metallic compounds in Fig. 1e are mainly compounds of $\mathrm{Al}, \mathrm{Cu}$, and Fe.

\subsection{Effect of solid solution on the microstructure of SiCp/Al-Si-Cu-Mg composite}

The hardness variation curve of the SiCp/Al-Si-Cu-Mg composite after the solid solution treatment at different temperatures for $4 \mathrm{~h}$, shown as Fig. 2. Vickers hardness of the composite before the heat treatment was $142.5 \mathrm{HV}$. Compared with the data in Fig. 2, it may be concluded that the hardness of the composite is obviously improved after the solid solution treatment. The solution temperature is between $470-520^{\circ} \mathrm{C}$, and the hardness of the SiCp/ $\mathrm{Al}-\mathrm{Si}-\mathrm{Cu}-\mathrm{Mg}$ composite is increased with the increase in the solution temperature. When the temperature is at $515{ }^{\circ} \mathrm{C}$, Vickers hardness of the composite reaches a peak, and then obviously decreases at $530{ }^{\circ} \mathrm{C}$. This is due to the thermal expansion coefficient between the SiC particles and the significantly different matrix alloy, which causes thermal mismatch. When the composites are subjected to the solution treatment, the thermal mismatch leads to the straining of the base alloy near the interface, and then produces high density of dislocations in the matrix alloy. The formula of dislocation density, caused by the thermal mismatch difference between the particles and the matrix, can be represented ${ }^{7}$ as:

$$
\rho=\frac{12 \Delta C \Delta T V_{\mathrm{P}}}{B d}
$$

where $V_{\mathrm{P}}$ is the volume fraction of the strengthening phases, $B$ is the Burgers vector, $d$ is the particle minimum size, $\Delta C$ is the thermal expansion coefficient of the composite reinforcement and matrix difference $\left(23.7 \times 10^{-6} / \mathrm{K}\right)$, and $\Delta T$ is the difference between the heat treatment temperature and room temperature.

It may be calculated from the formula that when other conditions remain unchanged, $\Delta T$ increases due to the rise in solid solution temperature, thereby causing an increase in dislocation density. Thus, when the composite material is subjected to the solution treatment, the temperature is higher (but no over-sintering under the premise), and the matrix atoms diffusion is more intense. At the same time, as the dislocation density is higher, the hardness of the composite increases. However, when the temperature is too high, the interface between the particles and the matrix may produce oxidation or solid-phase chemical reaction, and then reduce the binding strength of the interface of the composite materials, resulting in decreased hardness of the composite materials. ${ }^{8}$

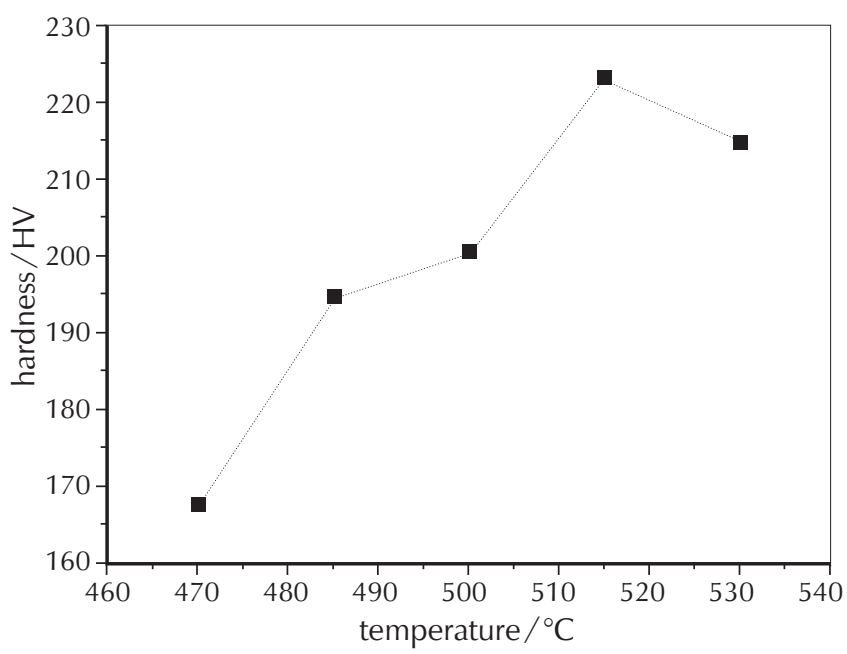

Fig. 2 - Hardening curve of the composites after solid solution at different temperatures

Fig. 3 shows the effect of solid solution time on the hardness of the $\mathrm{SiCp} / \mathrm{Al}-\mathrm{Si}-\mathrm{Cu}-\mathrm{Mg}$ composite at $515^{\circ} \mathrm{C}$. It may be seen that the hardness of the composites increases with the extension of solid solution time. When the time is $4 \mathrm{~h}$, Vickers hardness of the composites reaches a peak. Its numerical value is 223.4 HV. When the composite materials undergo solid solution treatment at $515{ }^{\circ} \mathrm{C}$, with the extension of time, the metallic compounds in the composite 


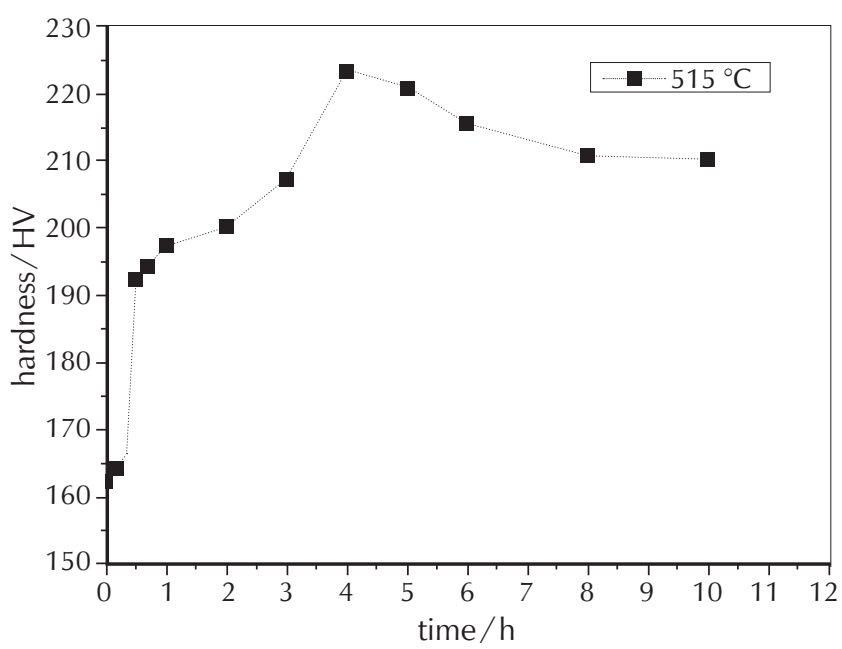

Fig. 3 - Hardening curve of the composites after solid solution for different time at $515{ }^{\circ} \mathrm{C}$

materials, which contain soluble elements such as $\mathrm{Mg}$, $\mathrm{Cu}$, gradually dissolve back into the matrix, and transform the lattice constant of the substrate in the grain, leading to lattice distortion. The effect of the solid solution strengthening is obvious; therefore, the hardness of the composites rises rapidly. At the same time, when the metallic compounds in the composite materials dissolve back into the matrix, the degree of the composite materials supersaturation increases and the solid solution strengthening effect is further enhanced. Therefore, the hardness of the composites continues to improve. When the holding time of the solid solution continues to extend the grain growth of the composites, it results in decreased hardness of the composites. ${ }^{9}$

As comprehensively described above, from the hardness curve of the composite undergoing different solid solution temperatures and times, it can be seen that, with the increase in solution temperature from 510 to $520{ }^{\circ} \mathrm{C}$, the mechanical properties of the composite material are more preferable. When the solution temperature is at $515{ }^{\circ} \mathrm{C}$, the hardness of the composite materials reaches a peak. During the solid solution treatment at $515{ }^{\circ} \mathrm{C}$ for different times, as the times changed, the composite solutionized at $515{ }^{\circ} \mathrm{C}$ for $4 \mathrm{~h}$, reached the highest peak. Therefore, by analysing the effect of the solution treatment on the hardness of the composite, the best treatment process for composite materials is the solid solution treatment at $515{ }^{\circ} \mathrm{C}$ for $4 \mathrm{~h}$.

\subsection{Effect of ageing on the mechanical properties of SiCp/Al-Si-Cu-Mg composite}

Based on the best solution treatment process, the process of the ageing treatment is studied. The variation curve of the hardness of the composite as a function of different ageing time at $160{ }^{\circ} \mathrm{C}$ and $180{ }^{\circ} \mathrm{C}$, respectively, after the solution treatment at $515{ }^{\circ} \mathrm{C}$ for $4 \mathrm{~h}$ is shown in Fig. 4 . It may be seen from Fig. 4 that the SiCp/Al-Si-Cu-Mg composite shows significant hardening phenomenon. The hardening curve of ageing at $180{ }^{\circ} \mathrm{C}$, for example, in the early ageing stage of the composites, along with the extension of ageing time, the hardness of the composites increases rapidly to a peak in a shorter time. After reaching the peak, the hardness of the composites begins to decline, reaching the bottom. When the ageing time continues to extend, the hardness of the composite begins to increase. Therefore, the second peak occurs, and with the extension of ageing time, the hardness of the composite material declines due to over-ageing. Ageing of the test samples has been carried out at temperatures of $160{ }^{\circ} \mathrm{C}$ and $180{ }^{\circ} \mathrm{C}$, during various ageing times of $0-20 \mathrm{~h}$. Every ageing temperature reached two peaks, named the "double peaks" phenomenon, and in between the two peaks, there is an obvious wave hollow.

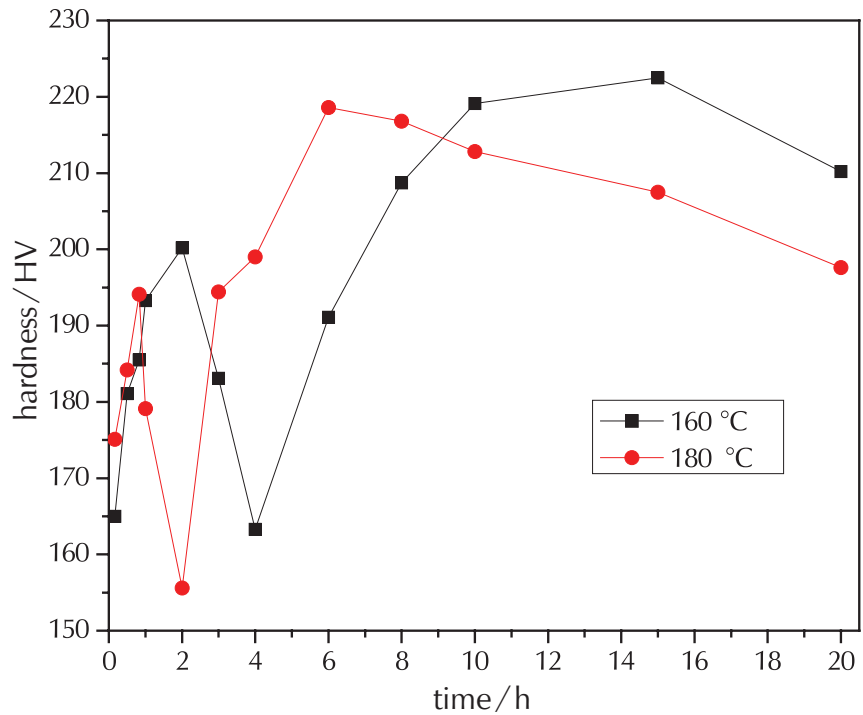

Fig. 4 - Microscopic hardening curve of different ageing temperatures and times

The SiCp/Al-Si-Cu-Mg composite of the "double peaks" phenomenon can be explained through the supersaturated solid solution desolventizing process. The desolventizing process of the $\mathrm{SiCp} / \mathrm{Al}-\mathrm{Si}-\mathrm{Cu}-\mathrm{Mg}$ composite is shown in Fig. 5.

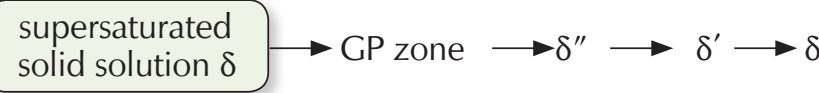

Fig. 5 - Supersaturated solid solution of desolventizing process

In the initial stages of ageing treatment, the supersaturated solid solution forms a large number of GP zones and remains in a coherent relationship with the matrix, therefore the hardness of the composites increases significantly, followed by the formation of the first peak. When the ageing time extends, the GP zone turns into the $\delta^{\prime \prime}$ phase. With the size growth of the $\delta^{\prime \prime}$ phase, the hardness of the composite material decreases. It appeared the first wave hollow. When the ageing time continues to extend, the 
$\delta^{\prime \prime}$ phase transforms toward the $\delta^{\prime}$ phase. The hardness of the composites rises, forming the second peak. The second peak is greater than the first peak, indicating that the effect of the $\delta^{\prime}$ phase strengthening is greater than that of the $\delta^{\prime \prime}$ phase. However, when the $\delta^{\prime}$ phase coarsens, the dislocation line can be bypassed, and the semi-coherent relationship will soon be destroyed, resulting in the declining hardness of the composites. Finally, growth of the $\delta$ phase precipitates leads to the hardness further decreasing. ${ }^{10-11}$

It may also be seen from Fig. 4, in comparison with the hardness curve of different ageing temperatures, as the ageing temperature rises, the hardness of the composite material peaks in a shorter time and the achieved peak values of the hardness are relatively lower. It can be concluded that, with the increase in ageing temperature, the hardening speed of the composite material increases, but at the same time the hardening ability reduces. This is because the low-temperature ageing is favourable in suppressing the transition from GP zone to metastable phase, so that the formation of GP zone has enough time and it is easy to form a small dense and a large number of GP zones. As the GP zone grows evenly, the number of ageing strengthening phases increases. With the increase in ageing temperature, the atomic vibrations are intensified, increasing the vacancy concentration of the matrix, thus speeding up the mutual diffusion between the solute atoms and vacancies. The GP zone easily grows up and the formation of the GP zone size is larger. The number of elements of the solid solution in the matrix, which can form GP zones, is constant, and it will inevitably cause a decrease in GP zone density. ${ }^{12-14}$ When the temperature reaches $160{ }^{\circ} \mathrm{C}$, the peak of the composite material is the highest, but the ageing time is too long (it needs $15 \mathrm{~h}$ ). Therefore, the ideal application is ageing treatment of the composite materials at $180{ }^{\circ} \mathrm{C}$ for $6 \mathrm{~h}$, which is based on the best solid solution treatment.

\subsection{Effect of ageing on the microstructure of SiCp/Al-Si-Cu-Mg composite}

With the solid solution treatment, the large metallic compounds dissolve back into the matrix of the composites, forming a supersaturated solid solution after rapid cooling. Following the ageing treatment, the supersaturated solute atoms of the matrix form nanometre-sized second phases. These ageing precipitated phases distribute the matrix as dispersion strengthening, thus improving the mechanical properties of the composites. Fig. 6 shows TEM images of the ageing treatment at $180{ }^{\circ} \mathrm{C}$ for different times after solid solution treatment at $500{ }^{\circ} \mathrm{C}$ during four hours. As may be seen from Fig. 6, a large number of GP zones and the disc-shaped or oval-shaped precipitates disperse through the aluminium matrix. The disc-shaped and oval-shaped precipitates were calibrated by diffraction pattern (Fig. 6e); the disc-shaped and oval-shaped precipitates are $\delta$ phase $\mathrm{Al}_{5} \mathrm{Cu}_{6} \mathrm{Mg}_{2}$. The $\delta$ phase is the cubic crystal structure. The lattice constant is $a=b=c=0.8311 \mathrm{~nm}$, along [1] zone axis.

The ageing process of the composite is also the diffusion process of atoms. In this study, the main factors affecting the diffusion of atoms are the ageing treatment process of the composites, which is mainly $\mathrm{Cu}, \mathrm{Mg}$ atomic diffusion process, and the ageing time. Therefore, the change in the number and size of metastable phases depends on the change in ageing treatment time. The change in the microstructure and size of the precipitated phase may be seen from Fig. 6 . In the early ageing treatment, the $\mathrm{Cu}, \mathrm{Mg}$
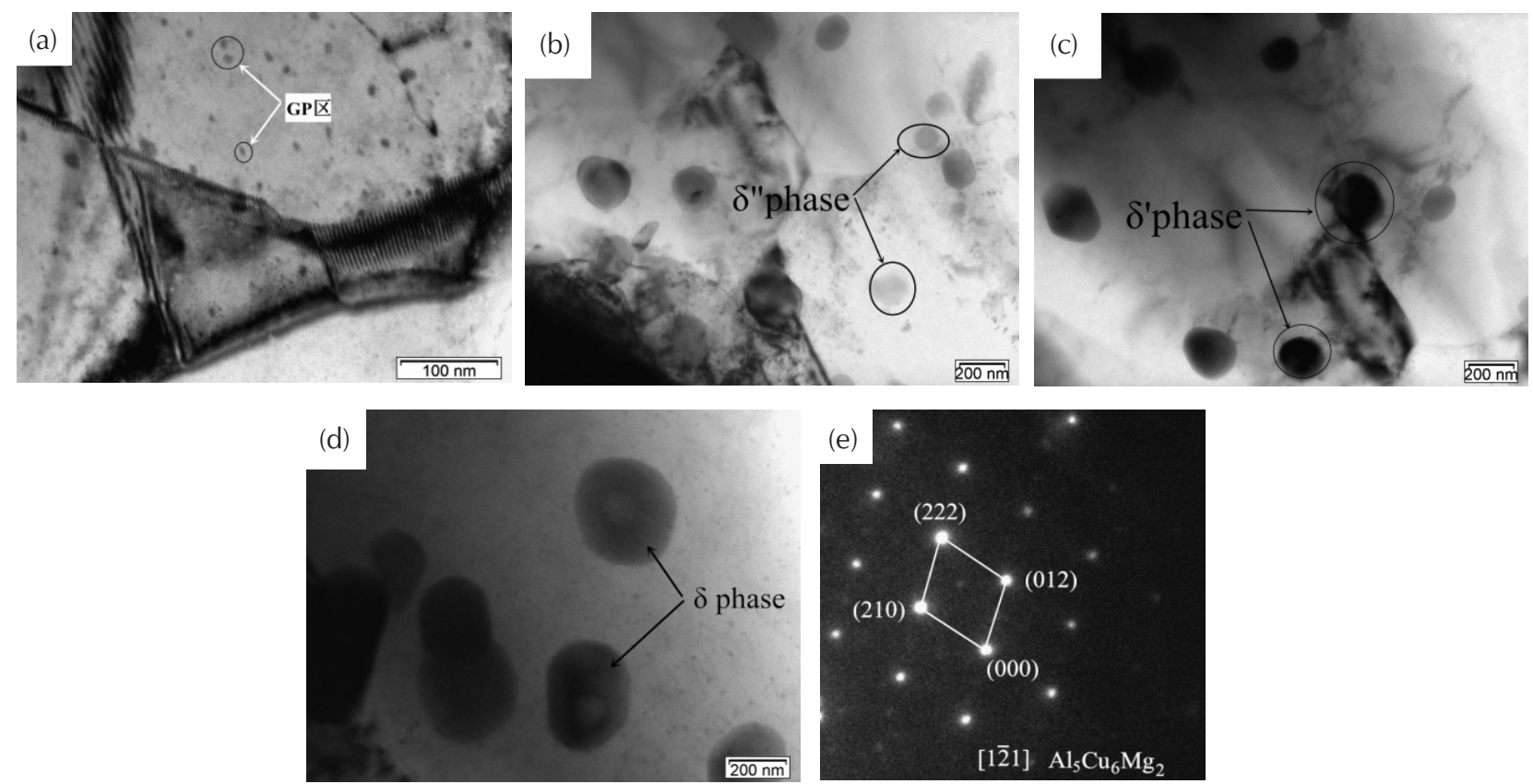

Fig. 6 - TEM and electron diffraction pattern of the precipitated phase at $180{ }^{\circ} \mathrm{C}$ for different ageing times: a) $10 \mathrm{~min}$; b) $2 \mathrm{~h}$; c) $4 \mathrm{~h}$; d) $10 \mathrm{~h}$; e) diffraction pattern of the second phase 
atoms accumulate in the crystal surface of the aluminium matrix, and gradually neatly form a solute atom-rich region (Fig. 6a), which is GP zone. Through quenching, the vacancies segregation atoms form a GP zone, which maintains a coherent relationship with the matrix. ${ }^{15-16}$ There are many GP zones in the matrix, resulting in a significant increase in the composites' hardness. When the ageing time extends, the GP zone turns into $\delta^{\prime \prime}$ phase, which then transforms toward the $\delta^{\prime}$ phase, and finally turns into the $\delta$ phase. When the second phases grow up and a merge occurs between phases (Fig. 6d), the SiCp/Al-Si-Cu-Mg composite is also in the over-ageing stage.

\section{Conclusions}

(1) With the increase in solution temperature, the metallic compounds gradually dissolve back into the matrix. When the solution temperature is $515{ }^{\circ} \mathrm{C}$, the second phase substantially dissolves back into the matrix, but very little amounts of the insoluble metallic compounds remain distributed in the matrix. The effect of the solid solution time on the hardness of the SiCp/ Al-Si-Cu-Mg composite at $515{ }^{\circ} \mathrm{C}$ for $4 \mathrm{~h}$ exhibits the highest peak.

(2) Following the ageing treatment, as the ageing time is extended, the hardness of the composite material reaches "double peak" phenomenon. The ideal application is ageing treatment of the composite materials at $180{ }^{\circ} \mathrm{C}$ for $6 \mathrm{~h}$, which is based on the best solid solution treatment.

(3) After the ageing treatment, there are many nanoscale precipitates in the composites, which are $\delta$ phase Al${ }_{5} \mathrm{Cu}_{6} \mathrm{Mg}_{2}$ by diffraction calibration. They can greatly improve the hardness of the composites.

\section{ACKNOWLEDGEMENTS}

This research was financially supported by the National Natural Science Foundation of China (No. 51371077).

\section{List of abbreviations and symbols}

EDS - energy-dispersive X-ray spectroscopy

GP - Guinier-Preston

SEM - scanning electron microscope

SiCp - SiC particles

TEM - transmission electron microscopy

$B$ - Burgers vector

$\Delta C \quad$ - thermal expansion coefficient

d $\quad-$ minimum size of the particle

$\Delta T$ - temperature difference

$V_{\mathrm{p}} \quad$ - volume fraction of the strengthening phases

w - mass fraction, $\%$

$x \quad-$ amount of substance fraction, $\%$

$\rho \quad-$ dislocation density

\section{References}

\section{Literatura}

1. X. L. Zhou, J. H. Wu, J. Y. Zhang, X. Z. Hua, Y. J. Zhou, A Review of Metal-Matrix Composites for Electronic Packaging, J. Nanchang Inst. Aeronaut. Technol. 15 (2001) 11-15, url: http://en.cnki.com.cn/Article en/CJFDTOTAL-NCHK200101002.htm.

2. M. W. Li, J. M. Han, Particle Agglomeration and Mechanical Properties of SiC_p/Al-Si Composites, Spec. Cast. Nonferr. Alloys 29 (1) (2009) 67-69, url: http://caod.oriprobe.com/ articles/15192177/Particle_Agglomeration_and_Mechanical_Properties_o.htm.

3. G. Z. Zhang, D. T. Lv, Z. M. Wu, Research of Fabrication and Application for SiCp Particle Reinforced Aluminum Matrix Composites, New Technol. New Proc. 11 (2010) 60-62, url: http://caod.oriprobe.com/articles/25634261/Research_of Fabrication_and_Application_for_SiCp_P.htm.

4. E. Jayakumar, J. C. Jacob, T. P. D. Rajan, M. A. Joseph, B. C. Pai, Processing and Characterization of Functionally Graded Aluminum (A319)-SiCp Metallic Composites by Centrifugal Casting Technique, Metal. Mater. Trans. A 47 (8), (2016) 4306-4315, doi: https://doi.org/10.1007/s11661-0163558-8.

5. J. Zhang, R. J. Perez, E. J. Lavernia, Dislocation induced damping in metal matrix composites, J. Mater. Sci. 28 (1993) 835-846, doi: https://doi.org/10.1007/bf01151266.

6. I. Özdemir, Ü. Cöcen, K. Önel, The effect of forging on the properties of particulate-SiC-reinforced aluminium-alloy composites, Compos. Sci. Technol. 60 (3) (2000) 411-419, doi: https://doi.org/10.1016/S0266-3538(99)00140-2.

7. Q. K. Cai, C. L. He, M. J. Zhao C. S. Liu, Tensile Properties and Strengthening Mechanisms of Pure Aluminum Matrix Composite Reinforced with Sub-micrometric SiC Particles, Acta Metall. Sin. 39 (8) (2003) 865-869, url: http://www. ams.org.cn/EN/Y2003/V39/18/865.

8. W. L. Gao, H. Su, H. Zhang, H. B. Liu, J. H. Wang, Microstructures and mechanical properties of spray co-deposited SiCp/2024 aluminum matrix composite synthesized by stir casting, Chin. J. Nonferr. Met. 20 (1) (2010) 49-54, url: http://www.cjonm.com/paper/paperView.aspx?id=paper_21887.

9. Z. Xie, J. Z. Fan, B. L. Xiao, T. Zuo, Behavior of Solution Treatment for SiCp/Al-Cu-Mg Composite Fabricated by Powder Metallurgy, Chin. J. Rare Metal. 32 (4) (2008) 433-436, url: http://caod.oriprobe.com/articles/14827233/Behavior_of Solution_Treatment_for_SiCp_Al_Cu_Mg_Composite_Fābricated.htm.

10. M. Zhao, G. H. Wu, L. T. Jiang, D. G. Sun, Aging Characteristics of a High Volume Fraction SiCp /LD2 Composite, Acta Materiae Compositae Sinica (AcMCS) 21 (3) (2004) 91-95, url: http:/caod.oriprobe.com/articles/7462906/AGING_CHARACTERISTICS_OF_A_HIGH_VOLUME_FRACTION_SiCP_LD2_COMPOSITĒ.htm.

11. M. F. Ibrahim, A. M. Samuel, H. W. Doty, F. H. Samuel, Effect of aging conditions on precipitation hardening in $\mathrm{Al}-\mathrm{Si}-\mathrm{Mg}$ and Al-Si-Cu-Mg alloys, Int. J. Metalcast. 11 (2) (2016) 274286, doi: https://doi.org/10.1007/s40962-016-0057-z.

12. S. Pal, R. Mitra, V. V. Bhanuprasad, Aging behaviour of Al-CuMg alloy-SiC composites, Mater. Sci. Eng. A 480 (1-2) (2008) 496-505, doi: https://doi.org/10.1016/j.msea.2007.07.072.

13. J. H. Cai, G. J. Shao, Research on Aging Process of Al-Mg-Si Alloys, Shanghai Metals 30 (2008) 16-18, url: http://en.oversea.cnki.net/kcms/detail/detail.aspx?QuerylD $=31 \&$ CurRec $=7 \&$ dbCode $=$ CJFD\&filename $=$ SHJI200804006\&dbname $=$ CJFD2008. 
14. X. Wang, S. Esmaeili, D. J. Lloyd, The sequence of precipitation in the Al-Mg-Si-Cu alloy AA6111, Metal. Mat Trans. A 37 (9) (2006) 2691-2699, doi: https://doi.org/10.1007/ BF02586103.

15. S. B. Hassan, O. Aponbiede, V. S. Aigbodion, Precipitation hardening characteristics of $\mathrm{Al}-\mathrm{Si}-\mathrm{Fe} / \mathrm{SiC}$ particulate compos- ites, J. Alloy Compd. 466 (1-2) (2008) 268-272, doi: https:// doi.org/10.1016/j.jallcom.2007.11.023.

16. X. L. Li, J. H. Chen, C. H. Liu, J. Feng, S. H. Wang, Effects of T6 and T8 Tempers on the Microstructures and Properties of AlMg-Si-Cu Alloys, Acta Metall. Sin. 49 (2013) 243-250, doi: https://doi.org/10.3724/SP.J.1037.2012.00509.

\section{SAŽETAK}

\section{Utjecaj otopine u čvrstom stanju i starenja na mikrostrukturu i mehanička svojstva kompozita čestica SiCp/Al-Si-Cu-Mg

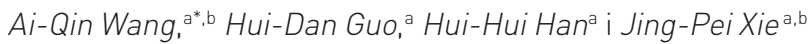

Pripravljen je kompozit čestica SiC (SiCp) u masenom udjelom 30 \% u matrici Al-Si-Cu-Mg prešanjem, sinteriranjem i ekstrudiranjem. Kompozit je 4 sata bio izložen otapanju u čvrstom stanju pri $470{ }^{\circ} \mathrm{C}, 485{ }^{\circ} \mathrm{C}, 500{ }^{\circ} \mathrm{C}, 515^{\circ} \mathrm{C}$ i $530{ }^{\circ} \mathrm{C}$. Nakon toga na uzorak je 4 sata pri $515^{\circ} \mathrm{C}$ djelovalo otapanje u čvrstom stanju, a zatim su uzorci starili različito vrijeme pri temperaturama 160 i $180^{\circ} \mathrm{C}$. Mikrostruktura i mehanička svojstva kompozita proučena su tehnikama pretražnom i transmisijskom mikroskopijom te analizom mikrotvrdoće. Pri sinteriranju kompozita SiCp/Al-Si-Cu-Mg nastaje bijeli zrnasti metalni spoj koji se otapa u čvrstu otopinu pri različitim temperaturama. Što je viša temperatura čvrste otopine, više se otopi metalnog spoja. Mikrotvrdoća doseže maksimum pri izlaganju reakcijama u čvrstom stanju pri $515^{\circ} \mathrm{C}$ kroz četiri sata. Nakon starenja i s produljenjem starenja tvrdoća materijala pokazuje dvostruki vrh.

$S$ povišenjem temperature povećava se brzina očvršćivanja, no istodobno se smanjuje mogućnost očvršćenja. Druga faza kompozita nakon starenja je diskoidni $\mathrm{Al}_{5} \mathrm{Cu}_{6} \mathrm{Mg}_{2}$.

\section{Ključne riječi}

Kompozit SiCp/Al-Si-Cu-Mg, obrada otopinom u čvrstom stanju, starenje, mikrostruktura, mikročvrstoća

a School of Materials Science and Engineering, Henan University of Science and Technology, Luoyang, Kina

${ }^{\mathrm{b}}$ Collaborative Innovation Center of Non-Ferrous Materials of Henan Province, Kina
Izvorni znanstveni rad Prispjelo 15. lipnja 2016. Prihvaćeno 21. rujna 2016. 